\title{
Struktur Modal berdasarkan Pecking Order Theory pada Perusahaan Makanan dan Minuman di Indonesia
}

\author{
Pandu Adi Cakranegara \\ cakranegara@gmail.com , \\ Program Studi Manajemen, Fakultas Bisnis, \\ Universitas Presiden, Cikarang, Indonesia \\ Debby Danilla Wati \\ debbywu100601@gmail.com \\ Program Studi Manajemen, Fakultas Bisnis, \\ Universitas Presiden, Cikarang, Indonesia
}

\begin{abstract}
Pecking Order theory states that management will prioritize its own capital before using debt. If it is forced to need additional funds then management will choose to owe rather than issue equity. This study examines the management behavior in the food and beverage industry in Indonesia. The food and beverage industry in Indonesia today is the industry with the highest growth in Indonesia. This means that companies need funding to be able to capture this momentum. The method used is a quantitative method using multiple regression analysis. The samples taken are all food and beverage companies listed on the Indonesian Stock Exchange. From the findings of management authors in food and beverage companies tend to use debt and equity issuance and do not use cash flow generated from business. One of the reasons for this is that the company uses all the cash generated from the operating proceeds to invest directly in the company's internal projects to increase growth.
\end{abstract}

Keywords: pecking order, equity, debt, cash flow from operations

\begin{abstract}
Abstrak
Teori Pecking Order menyebutkan bahwa manajemen akan mengutamakan modal sendiri sebelum menggunakan utang. Jika terpaksa membutuhkan tambahan dana maka manajemen akan memilih berutang daripada menerbitkan ekuitas. Penelitian ini meneliti mengenai perilaku manajemen di industri makanan dan minuman di Indonesia. Industri makanan dan minuman di Indonesia saat ini adalah industri yang memiliki pertumbuhan paling tinggi di Indonesia. Artinya perusahaan memerlukan pendanaan untuk dapat mengambil momentum ini. Metode yang digunakan adalah metode kuantitatif dengan menggunakan analisis regresi berganda. Sampel yang diambil adalah seluruh perusahaan makanan dan minuman yang terdaftar di Bursa Efek Indonesia. Dari hasil temuan penulis manajemen di perusahaan makanan dan minuman cenderung menggunakan utang dan penerbitan ekuitas dan tidak menggunakan arus kas yang dihasilkan dari usaha. Salah satu alasan dari hal ini adalah perusahaan menggunakan seluruh kas yang dihasilkan dari hasil operasi untuk langsung diinvestasikan pada proyek internal perusahaan guna meningkatkan pertumbuhan.
\end{abstract}

Kata kunci: pecking order, ekuitas, utang, arus kas operasi

\section{PENDAHULUAN}

Bank Dunia (2019) dalam laporannya menyebutkan bahwa konsumsi makanan dan minuman menjadi faktor pendorong terbesar konsumsi swasta di Indonesia. Soei et al., (2017) menyebutkan ada 
keterkaitan erat antara pertumbuhan Produk Domestik Bruto dengan konsumsi makanan dan minuman. Secara khusus penelitan dari Soei et al., (2017) menyebutkan bahwa peningkatan konsumsi makanan berpengaruh signifikan pada tingkat imbal balik perusahaan makanan dan minuman yang terdaftar di pasar modal.

Brigham (2019) menyebutkan terdapat hubungan antara pertumbuhan dan kebutuhan dana investasi. Kebutuhan dana investasi ini dapat diperoleh dari sumber-sumber pendanaan perusahaan yaitu pendanaan internal dan eksternal. Pendanaan eksternal terdiri dari utang dan penjualan kepemilikan perusahaan. Setiap keputusan pendanaan perusahaan akan menimbulkan kos. Perusahaan dapat meningkatkan nilai dengan cara memilih kombinasi pendanaan yang meminimalkan kos tanpa mengorbankan arus kas yang diterima perusahaan (Damodaran, 2019).

Setiap perusahaan akan menghadapi pilihan dalam mengelola kos modalnya. Nugroho (2006) menemukan bahwa pertumbuhan perusahaan mempunyai pengaruh signifikan terhadap pilihan struktur modal. Berangkat dari hal tersebut maka penelitian ini meneliti hubungan antara pemilihan struktur modal perusahaan di perusahaan makanan dan minuman yang industrinya mengalami pertumbuhan tertinggi di Indonesia. Penelitian ini menggunakan sudut pandang teori Pecking Order . Jika teori Pecking Order berlaku di Indonesia maka perusahaan akan memilih menggunakan sumber dana dalam urutan tertentu yaitu sumber dana internal perusahaan, sumber dana dari utang dan sumber dana dari penjualan kepemilikan (Frank et al., 2003).

\section{LANDASAN TEORI}

Myers (1984) meneliti pemilihan struktur modal perusahaan. Ia menyebutkan bahwa ada teka-teki dalam pilihan pendanaan. Teka-teki ini timbul karena perusahaan tidak selalu menggunakan utang walaupun utang tersebut dapat mengurangi utang karena memiliki kemampuan untuk mengurangi pajak dan selanjutnya memperkecil kos modal. Yang terjadi adalah ada semacam urutan dalam pemilihan sumber pendanaan yaitu pertama yang cenderung digunakan oleh manajemen adalah dana internal, kemudian utang dan kemudian penjualan kepemilikan.

Myers (2001) dalam penelitian selanjutnya menyebutkan bahwa hal ini akan terjadi ketika terjadi disparitas informasi antara perusahaan dan investor. Manajemen perusahaan adalah pihak yang paling mengerti tentang prospek dari sebuah kesempatan investasi. Sementara itu pihak investor luar adalah pihak yang berusaha menerka seberapa menarikkah kesempatan investasi yang dimiliki oleh manajemen dengan memanfaatkan sarana-sarana informasi yang tersedia seperti laporan keuangan perusahaan dan data-data ekonomi lainnya.

Shyam-Sunder et al (1999) menyebutkan bahwa terdapat kos atas informasi. Kos atas informasi ini memiliki hubungan terbalik dengan kos modal yang disyaratkan oleh investor. Pada penerbitan ekuitas informasi yang dimiliki oleh investor lebih rendah dari pada informasi yang dimiliki oleh investor yang memberikan utang. Dichev et al (2002) menerangkan bagi investor utang ketimpangan informasi yang ada dapat dikurangi oleh pemberi utang dengan meminta covenant dari perusahaan.

Menurut Damodaran (2016) arus kas bebas adalah arus kas yang dapat dikelola manajemen. Ini artinya karena arus kas bebas berada di bawah manajemen langsung maka manajemen memiliki keleluasaan dalam mengelolanya. Keleluasaan ini diwujudkan manajemen dalam berinvestasi di proyek-proyek yang menurut manajemen memiliki peluang yang menguntungkan tanpa perlu mengkhawatirkan konservatisme dari investor eksternal (Brush et al., 2000).

\section{METODE PENELITIAN}

Metode Penelitian yang digunakan dalam penelitian ini adalah metode penelitian kuantitatif dengan menggunakan analisa regresi berganda. Metode penelitian berganda dipilih karena dapat mengukur hubungan antara beberapa variabel independen dengan variabel dependen. Dari regresi berganda dapat diketahui variabel yang berpengaruh dan model yang dapat menjelaskan variabel dependen (Peck, 2015). 


\title{
Kriteria sampel
}

Sampel yang dipilih dalam penelitian ini adalah semua perusahaan makanan dan minuman yang terdaftar di Bursa Efek Indonesia pada periode 2015 hingga periode 2019. Sampel yang digunakan adalah sampel purposive dengan kriteria yang ditetapkan di awal (Etikan et al., 2016). Kriteria sampel terdiri dari empat kriteria. Kriteria pertama adalah perusahaan makanan dan minuman yang terdaftar di Bursa Efek Indonesia pada periode 2015 hingga 2019. Kriteria kedua, perusahaan paling lambat melantai di bursa pada tahun 2014. Kriteria ketiga, perusahaan memiliki laporan keuangan yang diaudit dengan hasil audit wajar tanpa pengecualian. Kriteria keempat, perusahaan yang memiliki data yang lengkap yang dibutuhkan oleh penelitian ini.

Dari keempat kriteria tersebut terpilih empat belas perusahaan yang memenuhi semua kriteria. Dari empat belas perusahaan itu masing-masing diambil data variabel dependen dan independennya. Selanjutnya dari sampel tersebut dilihat persebaran datanya untuk mencari tahu apakah data terdistribusi normal (Park, 2015). Data yang tersebar jauh atau outlier kemudian dikeluarkan. Akhirnya terpilih dua belas perusahaan. Dari kedua belas perusahaan terkumpul enam data untuk masing-masing perusahaan.

Data yang digunakan adalah data panel yang karena menggunakan lebih dari satu variabel selama beberapa tahun. Data panel memiliki keunggulan karena mampu menangkap perilaku manusia yang kompleks dengan melihatnya tidak hanya dalam suatu titik waktu melainkan dalam suatu kurun waktu (Hsiao, 2007). Setiap tahun terdapat enam data untuk masing-masing perusahaan yang terdiri dari satu data untuk variabel dependen dan lima data untuk variabel independen. Periode sampel mulai tahun 2015 hingga tahun 2019 yang berarti terdapat data untuk lima tahun periode.

\section{Hipotesis dan variabel}

Penelitian ini meneliti pengaruh dari pemilihan struktur modal terhadap imbal balik perusahaan. Variabel dependen adalah imbal balik perusahaan dengan menggunakan Return On Asset sebagai indikatornya. Variabel independen terdiri dari Cash Flow from Operations, Cash Flow from Financing, Debt to Asset Ratio, Debt to Asset Ratio, dan Long Term Debt.

Dalam penelitian ini dikembangkan enam hipotesis yaitu

$H_{1}$ : Terdapat pengaruh signifikan antara Debt to Asset Ratio dengan Return On Asset.

$\mathrm{H}_{2}$ : Terdapat pengaruh signifikan antara Debt to Asset Ratio dengan Return On Asset.

$H_{3}$ : Terdapat pengaruh signifikan antara Long Term Debt dengan Return On Asset.

$H_{4}$ : Terdapat pengaruh signifikan antara Cash Flow from Operations dengan Return On Asset.

$H_{5}$ : Terdapat pengaruh signifikan antara Cash Flow from Financing dengan Return On Asset.

$H_{6}:$ Terdapat pengaruh simultan antara Debt to Asset Ratio, Debt to Asset Ratio, Long Term Debt, Cash Flow from Operations, dan Cash Flow from Financing dengan Return On Asset.

\section{PEMBAHASAN}

\begin{abstract}
Analisa statistik
Dari hasil analisa statistik menggunakan piranti lunak EViews didapati keluaran seperti pada tabel 1 di bawah ini. Dari hasil keluaran tersebut terdapat tiga variabel independen yang secara signifikan mempengaruhi variabel dependen. Tiga variabel tersebut adalah Debt to Asset Ratio, Debt to Asset Ratio dan Long Term Debt. Dua variabel yaitu Debt to Asset Ratio memiliki tingkat probabilitas yang sangat tinggi yaitu di bawah satu persen. Sedangkan variabel Debt to Asset Ratio memiliki probabilitas yang tinggi yaitu dua persen.
\end{abstract}




\section{Uji hipotesis}

Dari enam hipotesis yang diajukan maka diterima empat hipotesis. Hipotesis yang ditolak adalah Hipotesis empat dan Hipotesis lima. Hipotesis yang diterima adalah Hipotesis satu, dua, tiga dan enam. Maka dapat disimpulkan:

Terdapat hubungan signifikan antara Debt to Asset Ratio dengan Return On Asset.

Terdapat hubungan signifikan antara Debt to Asset Ratio dengan Return On Asset.

Terdapat hubungan signifikan antara Long Term Debt dengan Return On Asset.

Terdapat hubungan simultan antara Debt to Asset Ratio, Debt to Asset Ratio, Long Term Debt, Cash Flow from Operations, dan Cash Flow from Financing dengan Return On Asset.

Model yang terbentuk dari regresi adalah

$\mathrm{ROA}=0,61+0,27 \mathrm{DER}-0,58 \mathrm{DAR}-2,88 \mathrm{LTD}+0,001 \mathrm{CF} 0+0,004 \mathrm{CFF}$

Di mana:

ROA: $\quad$ Return On Asset

DAR: $\quad$ Debt to Asset Ratio

DER: $\quad$ Debt to Equity Ratio

LTD: $\quad$ Long Term Debt

CFO: $\quad$ Cash Flow from Operations

CFF: $\quad$ Cash Flow from Financing

Tabel 1. Hasil Luaran Regresi Berganda

\begin{tabular}{ccccc}
\hline Dependent Variable & \multicolumn{4}{c}{ Return On Asset } \\
\hline Variable & Coefficient & Std. Error & t-Statistic & Prob. \\
\hline C & 0.608 & 0.128 & 4.750 & $0.000^{* * * *}$ \\
DER & 0.267 & 0.110 & 2.405 & $0.021^{* * *}$ \\
DAR & -0.584 & 0.087 & -6.712 & $0.000^{* * *}$ \\
LTD & -2.879 & 0.411 & -7.006 & $0.000^{* * *}$ \\
CFO & 0.001 & 0.004 & 0.231 & 0.819 \\
CFF & 0.004 & 0.003 & 2.178 & 0.885 \\
\hline R-squared & 0.788 & Mean dependent var & 0.054 \\
Adjusted R-squared & 0.709 & S.D. dependent var & 0.373 \\
S.E. of regression & 0.201 & Akaike info criterion & -0.134 \\
Sum squared resid & 1.742 & Schwarz criterion & 0.046 \\
Log likelihood & 21.041 & Hannan-Quinn criter. & 0.097 \\
F-statistic & 10.003 & Durbin-Watson stat & 2.178 \\
Prob (F-statistic) & 0.000 & & \\
\hline
\end{tabular}

Sumber: Olah data penulis, 2020

\section{DISKUSI}

Uji hipotesis menunjukkan bahwa manajer cenderung memilih pendanaan eksternal yang terlihat dari pengaruh signifikan antara proksi pendanaan luar yaitu Debt to Asset Ratio, Debt to Asset Ratio dan Long Term Debt dengan tingkat keuntungan perusahaan dengan proksi Return On Asset.

Ada beberapa faktor yang mendorong hal ini dilihat dari beberapa sisi. Sudut pandang yang diambil dapat berasal dari sudut pandang internal yaitu manajemen sendiri dan sudut pandang eksternal yaitu kreditor dan investor.

Sudut pandang pertama dari sudut pandang investor ekuitas. Investor ekuitas terdiri dari beberapa tipe investor. Satu hal yang dilihat dari sudut pandang investor ekuitas dalam menyusun portofolio adalah tipe industri. Sektor makanan dan minuman adalah sektor yang bersifat defensif. Artinya saham pada sektor ini akan tetap bertahan karena produknya tetap dikonsumsi oleh masyarakat 
walaupun kondisi ekonomi menurun. Pada saat pertumbuhan ekonomi melambat maka investor akan meningkatkan bobot saham defensif dalam portofolionya (Ilmanen et al., 2015). Ini berarti investor akan membeli lebih banyak saham perusahaan makanan dan minuman. Ketika permintaan saham meningkat maka harga saham akan meningkat dan return bagi pemegang saham akan meningkat.

Sudut pandang kedua dari pemberi utang. Dari sampel yang ada perusahaan-perusahaan di sektor makanan dan minuman mendapatkan pendanaan utang dari bank. Bank dalam memberikan kreditnya memiliki beberapa kriteria (Kiss, 2003). Kriteria keuangan pertama yang dilihat dari bank adalah arus kas bersih yang dimiliki perusahaan. Sektor makanan dan minuman menyumbang pendapatan sektor swasta terbesar di Indonesia pada periode 2015 hingga 2019 (World Bank, 2019). Ini berarti industri makanan dan minuman mendapatkan kue konsumsi konsumen paling banyak dibandingkan dengan industri lainnya. Jika diterjemahkan ke arus kas maka industri makanan dan minuman mendapatkan arus kas bebas yang lebih besar dibandingkan industri lainnya. Kriteria keuangan kedua yang dilihat bank adalah jaminan. Perusahaan makanan dan minuman merupakan sektor yang memiliki aset tetap berupa pabrik dan persediaan yang besar. Ini dapat digunakan untuk jaminan bagi bank. Kriteria keuangan ketiga adalah keberlanjutan. Sektor makanan dan minuman memiliki keberlanjutan yang baik karena produk di dalamnya telah memiliki konsumen yang akan mengonsumsi barangnya dalam kurun waktu yang rutin. Ketiga kriteria ini yang membuat bank tidak segan untuk memberikan pendanaan kepada industri makanan dan minuman terutama ketika industri ini sedang bertumbuh.

Sudut pandang ketiga dari manajemen internal. Manajemen internal akan berusaha meminimalkan kos modal untuk meningkatkan nilai perusahaan (Damodaran, 2016). Salah satu cara untuk meminimalkan kos modal adalah dengan mengelola jumlah utang dan ekuitas yang dimiliki perusahaan (Brigham, 2019). Penggunaan utang memiliki manfaat karena mampu memberikan perlindungan pajak atau tax shield yang akan mengurangi kos modal jika ditambahkan dengan kos ekuitas yang dimiliki perusahaan (Kemsley, 2002).

Dari data laporan keuangan perusahaan makanan dan minuman di dalam sampel yang digunakan dalam penelitian ini terlihat bahwa pengeluaran arus kas pada Cash Flow from Financing lebih tinggi dari Cash Flow from Operations. Ini berarti lebih banyak uang kas yang keluar untuk keperluan pendanaan daripada arus kas yang didapatkan perusahaan dari arus kas operasi. Arus kas pendanaan terutama untuk pendanaan jangka pendek yaitu membeli persediaan. Artinya perusahaan terus menambah persediaan. Hal ini menunjukkan bahwa perusahaan meningkatkan produksi untuk merespons terhadap kenaikan permintaan barang dari konsumen (Hay, 1994). Oleh karena itu maka manajemen memerlukan alternatif pendanaan dari luar untuk menutup kekurangan dana.

\section{KESIMPULAN}

Hasil penelitian ini menunjukkan bahwa teori Pecking Order pada perusahaan makanan dan minuman di Indonesia terbukti. Manajemen menggunakan dana internal terlebih dahulu untuk mendanai kegiatan perusahaan dalam hal ini adalah meningkatkan jumlah persediaan. Baru ketika dana yang ada kurang maka manajemen mencari alternatif lain yaitu dana eksternal. Dalam periode tahun 2015 hingga 2019 dengan adanya pertumbuhan tingkat konsumsi masyarakat terhadap makanan dan minuman (World Bank, 2019) maka mendorong perusahaan makanan dan minuman untuk meningkatkan produksi.

\section{Saran}

Penelitian ini dilakukan pada saat kondisi perekonomian sedang mengalami perlambatan dan industri bahan makanan menjadi industri dengan pertumbuhan tertinggi di Indonesia. Ke depannya dapat diteliti periode-periode lain ketika industri makanan tidak berada di puncak konsumsi swasta untuk mengetahui variasi dari pengambilan keputusan struktur modal oleh manajemen.

Hal lain yang dapat diteliti lebih lanjut adalah jika tren konsumsi pertumbuhan industri makanan dan minuman terus berlanjut. Jika tren ini terus berlanjut maka perusahaan makanan dan minuman tidak dapat mengandalkan aset yang ada sekarang untuk meningkatkan produksi. Akibatnya perusahaan perlu berinvestasi pada aset tetap. Investasi pada aset tetap adalah investasi jangka panjang dan berbeda dengan investasi pada persediaan. Pada kondisi seperti ini dapat diteliti apakah manajemen akan tetap menggunakan utang atau lebih memilih menerbitkan ekuitas (Fillbeck et al., 2000). 


\section{DAFTAR PUSTAKA}

Eugene B. F., \& Ehrhardt, M. C. (2019). Financial management: Theory \& practice. Cengage Learning

Brush, T.H., Bromiley, P. \& Hendrickx, M., (2000). The free cash flow hypothesis for sales growth and firm performance. Strategic Management Journal, 21(4), 455-472.

Damodaran, A., (2016). Damodaran on valuation: Security analysis for investment and corporate finance (Vol. 324). John Wiley \& Sons.

Dichev, I.D. \& Skinner, D.J., (2002). Large-sample evidence on the debt covenant hypothesis. Journal of Accounting Research, 40(4), 1091-1123.

Etikan, I., Musa, S.A. \& Alkassim, R.S., (2016). Comparison of convenience sampling and purposive sampling. American Journal of Theoretical and Applied Statistics, 5(1), 14.

Filbeck, G. \& Gorman, R.F., (2000). Capital structure and asset utilization: The case of resource intensive industries. Resources Policy, 26(4), 211-218.

Frank, M.Z. \& Goyal, V.K., 2003. Testing the pecking order theory of capital structure. Journal of Financial Economics, 67(2), 217-248.

Hay, D. \& Louri, H., (1994). Investment in inventories: An empirical microeconomic model of firm behaviour. Oxford Economic Papers, 157-170.

Hsiao, C., (2007). Panel data analysis - advantages and challenges. Test, 16(1), 1-22.

Ilmanen, A., Nielsen, L. \& Chandra, S., (2015). Are defensive stocks expensive? A closer look at value spreads. White Paper, AQR.

Kemsley, D. \& Nissim, D., (2002). Valuation of the debt tax shield. The Journal of Finance, 57(5), 2045-2073.

Kiss, F., (2003). Credit scoring processes from a knowledge management perspective. Periodica Polytechnica Social and Management Sciences, 11(1), 95-110.

Myers, S.C., (1984). The capital structure puzzle. Journal of Finance, 39, 575-592

Myers, S.C., (2001). Capital structure. Journal of Economic Perspectives, 15, 81-102.

Nugroho, A. (2006). Analisis faktor-faktor yang mempengaruhi struktur modal perusahaan yang go-public di Bursa Efek Jakarta untuk periode tahun 1994-2004. Tesis. Semarang: Universitas Diponegoro.

Park, H.M., (2015). Univariate analysis and normality test using SAS, Stata, and SPSS.

Peck, R., Olsen, C. \& Devore, J.L., (2015). Introduction to statistics and data analysis. Cengage Learning.

Shyam-Sunder, L., Myers, S.C., (1999). Testing static tradeoff against pecking order models of capital structure. Journal of Financial Economics, 51, 219-244

Soei, T. L. C., Dewi, V.I. \& Oriana, F., (2017). Pengaruh faktor ekonomi terhadap profitabilitas pada perusahaan fast moving consumer good yang terdaftar di Bursa Efek Indonesia.

World Bank, (2019). The World Bank Annual Report 2019. The World Bank. 